\title{
PENERAPAN MODEL PEMBELAJARAN INKUIRI TERBIMBING TERHADAP HASIL BELAJAR SISWA PADA MATERI POKOK SUHU DAN KALOR DI SMA NEGERI 15 MEDAN
}

\author{
Eidi Sihombing*) dan Gressy D Sihombing **) \\ (Prodi Pendidikan Fisika FMIPA Unimed) \\ gracesihombing325@yahoo.co.id \\ *) Dosen Fisika Unimed \\ **) Mahasiswi Pendidikan Fisika Unimed
}

\begin{abstract}
ABSTRAK
Penelitian ini bertujuan untuk mengetahui pengaruh model pembelajaran inkuiri terbimbing terhadap hasil belajar fisika siswa pada materi pokok Suhu dan Kalor di kelas X SMA Negeri 15 Medan Tahun Pelajaran 2014/2015. Jenis penelitian ini adalah penelitian quasi eksperimen dengan populasi seluruh siswa kelas X SMA Negeri 15 Medan yang terdiri dari 10 kelas dengan sampel penelitian diambil 2 kelas yang ditentukan dengan teknik cluster random sampling. Instrumen yang digunakan adalah tes hasil belajar siswa dalam bentuk essay sebanyak 8 soal yang telah divalidasi. Untuk menguji hipotesis digunakan uji beda (uji t), setelah uji prasyarat dilakukan, yaitu uji normalitas dan uji homogenitas. Hasil penelitian menunjukkan bahwa model pembelajaran inkuiri terbimbing dapat meningkatkan hasil belajar dan aktivitas siswa dari pertemuan I sampai dengan III.
\end{abstract}

Kata Kunci : inkuiri terbimbing, hasil belajar, aktivitas

\begin{abstract}
This research aimed to determine the effect of guided inquiry learning model on physics learning outcomes of students in the subject matter heat and temperature for X class SMA Negeri 15 Medan in 2014/2015 academic year. The research was quasi-experimental with the entire population of tenth grade students of SMA Negeri 15 Medan. The instrument used in this search is test of learning outcomes in the form of essay with 8 questions that have been declared valid. To test the hypothesis used different test ( $t$ test), after the prerequisite test is done, the test of normality and homogeneity tests. The results showed that the guided inquiry learning can improve student learning outcome and activity from the first meeting up to the third meeting.
\end{abstract}

Kata Kunci : guided Inquiry, learning outcomes, activities.

\section{PENDAHULUAN}

Pendidikan adalah investasi manusia memperoleh pengakuan dari banyak kalangan ahli. Kualitas SDM sangat bergantung pada kualitas pendidikan. Jika tidak mampu

mengembangkan SDM, suatu bangsa tidak akan dapat membangun negaranya. Oleh karena itu, pengembangan dan pembangunan SDM merupakan salah satu syarat 
yang penting bagi pembangunan (Kunandar, 2007:10).

Masalah utama dalam pembelajaran pada pendidikan dewasa ini adalah masih rendah daya serap peserta didik. Prestasi ini tentunya merupakan hasil kondisi pembelajaran yang bersifat konvensional dan tidak menyentuh ranah dimensi peserta didik itu sendiri. (Trianto, 2011:5). Masalah ini juga terjadi pada pelajaran fisika, hal ini dikarenakan fisika merupakan salah satu cabang sains, yang menekankan pada pemberian pengalaman langsung untuk mengembangkan kompetensi agar siswa menjelajahi dan memahami konsep fisika.

Masalah-masalah dalam pelajaran fisika dapat dikurangi dengan memilih model pembelajaran yang tepat. Jika seseorang belajar konsep-konsep fisika dengan benar, seharusnya ia mampu memecahkan masalah-masalah yang tak terlihat dalam fisika (Husein, et all, 2011: 269).

Pemahaman yang benar akan pelajaran fisika akan sangat berpengaruh terhadap hasil belajar siswa. Akan tetapi, fakta dilapangan menunjukkan bahwa aktivitas belajar fisika siswa masih kurang atau tidak sesuai dengan yang diharapkan (Rachman dkk., 2012:300).

Kenyataan tersebut tampak berdasarkan hasil wawancara yang dilakukan di SMA Negeri 15 Medan kepada guru mata pelajaran Fisika, diperoleh data bahwa $67,5 \%$ siswa memiliki nilai pelajaran fisika di bawah KKM. Hal ini relevan dengan data yang diperoleh dari angket yang diberikan kepada 40 siswa. Sebanyak $32,5 \%$ (13 orang siswa) berpendapat fisika adalah pelajaran yang sulit dipahami dan kurang menarik, 47,5 $\%$ (29 orang siswa) berpendapat fisika biasa - biasa saja, dan hanya $20 \%$ (8 orang siswa) yang berpendapat fisika mudah dan menyenangkan.

Faktor yang menyebabkan rendahnya hasil belajar siswa berdasarkan wawancara kepada guru fisika dan penyebaran angket pada salah satu kelas X, yaitu metode dan model pembelajaran fisika kurang bervariasi. Dalam pembelajaran fisika lebih dominan menggunakan pembelajaran yang kovensional dengan metode ceramah, mencatat, mengerjakan soal. Sehingga guru sebagai satu-satunya penyedia informasi dan pembelajaran masih berpusat kepada guru. Keaktifan dan keterlibatan siswa juga masih kurang. Ketika guru mengajukan pertanyaan, siswa yang menjawab pertanyaan guru cenderung didominasi oleh beberapa orang saja. Hal ini disebabkan karena kurangnya minat belajar siswa dalam mempelajari pelajaran fisika. Selain itu tidak adanya kerja sama antara siswa yang berkemampuan berpikir yang tinggi dengan siswa yang berkemampuan berpikir rendah selama proses pembelajaran berlangsung.

Model pembelajaran inkuiri terbimbing ini merupakan salah satu model pembelajaran yang sangat cocok untuk di terapkan dalam suatu pokok bahasan mata pelajaran fisika. Menurut Sanjaya (2011:196), model pembelajaran inkuiri adalah rangkaian pembelajaran yang menekankan pada proses berpikir secara kritis dan analisis untuk mencari dan menemukan sendiri 
jawaban dari suatu masalah yang dipertanyakan.

Inkuiri terbimbing adalah suatu model pembelajaran dimana siswa menemukan dan menggunakan sumber, informasi, dan ide yang bermacam-macam untuk menambahi pengetahuan mereka terhadap suatu masalah, topik dan isu-isu (Ngozi, et all, 2013:36). Konsep dari model inkuiri terbimbing telah banyak digunakan para pendidik dan sudah menjadi bagian dari filsafat pendidikan. Model ini juga menghadapkan siswa terhadap suatu masalah untuk dipecahakan sehingga dapat menambah motivasi siswa. Dan yang lebih penting, inkuiri terbimbing melibatkan siswa menjadi lebih aktif selama proses belajar mengajar dan megizikan siswa untuk mempelajari diri sendiri, hal ini memiliki keuntungan dimana siswa dapat memahami lebih dalam terhadap konsep-konsep dan menajadi pemikir yang kritis (Wang, et all, 2011). Hal ini juga sesuai dengan penelitian Vlassi, et all, (2013), yang mengatakan bahwa inkuiri terbimbing adalah pembelajaran konstruktivisme yang berpusat pada siswa.

$$
\text { Peranan guru saat }
$$

melaksanakan model pembelajaran inkuiri adalah memfasilitasi setiap tahap proses inkuiri dan membantu siswa dalam memusatkan perhatian dan merefleksikan proses berpikir. Meskipun ada banyak variasi model pembelajaran inkuiri, secara keseluruhan tahap pelaksaannya terdiri atas enam tahap (Arends, 2012:343). Keenam tahap tersebut ditunjukkan pada Tabel 1
Tabel 1. Sintaks Model Pembelajaran Inkuiri Terbimbing

\begin{tabular}{|c|c|}
\hline Tahap & Perilaku Guru \\
\hline $\begin{array}{l}\text { Menarik perhatian } \\
\text { dan menjelaskan } \\
\text { proses inkuiri. }\end{array}$ & $\begin{array}{l}\text { Guru mempersiapkan } \\
\text { siswa untuk belajar } \\
\text { dan memberikan } \\
\text { gambaran mengenai } \\
\text { proses pembelajaran. }\end{array}$ \\
\hline $\begin{array}{l}\text { Menampilkan } \\
\text { permasalahan atau } \\
\text { kejadian yang } \\
\text { menarik perhatian. }\end{array}$ & $\begin{array}{l}\text { Guru menampilkan } \\
\text { situasi masalah atau } \\
\text { kejadian yang } \\
\text { menarik perhatian } \\
\text { kepada siswa. }\end{array}$ \\
\hline $\begin{array}{l}\text { Merumuskan } \\
\text { hipotesis untuk } \\
\text { menjelaskan masalah } \\
\text { atau kejadian. }\end{array}$ & $\begin{array}{l}\text { Guru mendorong } \\
\text { siswa untuk bertanya } \\
\text { mengenai situasi } \\
\text { masalah dan } \\
\text { merumuskan } \\
\text { hipotesis dari apa } \\
\text { yang akan diselidiki. }\end{array}$ \\
\hline $\begin{array}{l}\text { Mengumpulkan data } \\
\text { untuk menguji } \\
\text { hipotesis. }\end{array}$ & $\begin{array}{l}\text { Guru bertanya kepada } \\
\text { siswa bagaimana cara } \\
\text { siswa mengumpulkan } \\
\text { data untuk menguji } \\
\text { hipotesis. Kasus yang } \\
\text { sama, di kelas } \\
\text { percobaan dapat } \\
\text { diterapkan. }\end{array}$ \\
\hline $\begin{array}{l}\text { Merumuskan } \\
\text { penjelasan dan/atau } \\
\text { kesimpulan. }\end{array}$ & $\begin{array}{l}\text { Guru mengakhiri } \\
\text { penyelidikan dengan } \\
\text { rumusan kesimpulan } \\
\text { siswa } \\
\text { generalisasi. }\end{array}$ \\
\hline $\begin{array}{lr}\text { Merefleksikan situasi } \\
\text { permasalahan } \\
\text { proses berpikir yang } \\
\text { digunakan } & \text { dalam } \\
\text { penyelidikan. } & \end{array}$ & $\begin{array}{l}\text { Guru menyuruh siswa } \\
\text { untuk memikirkan } \\
\text { proses berpikirnya } \\
\text { dan merefleksikannya } \\
\text { dalam proses } \\
\text { penyelidikan. }\end{array}$ \\
\hline
\end{tabular}

Model inkuiri terbimbing ini pernah diteliti oleh beberapa peneliti sebelumnya, diantaranya; Seraphin, et all. (2012) bahwa model pembelajaran inkuiri lebih sukses dari pada pembelajaran tradisional dalam meningkatkan pemahaman konseptual. 
Sehingga penerapan model pembelajaran inkuiri menjadi salah satu solusi untuk mengasah kemampuan berpikir siswa. Njoroge, et all, (2014: 14) mengatakan bahwa adanya peningkatan hasil belajar siswa dengan menggunakan inkuiri.

Adapun yang menjadi tujuan penelitian adalah untuk mengetahui pengaruh model pembelajaran inkuiri terbimbing terhadap hasil belajar siswa pada materi pokok Suhu dan Kalor di kelas X Semester II SMA Negeri 15 Medan T.P. 2015/2016 dan mengetahui aktivitas belajar siswa selama Proses Belajar Mengajar (PBM) .

\section{METODE PENELITIAN}

Penelitian ini dilaksanakan di SMA Negeri 15 Medan dengan populasi seluruh siswa kelas X SMA Negeri 15 Medan yang terdiri dari 10 kelas. Teknik pengambilan sampel dilakukan dengan cara tehnik sampel kelas acak (cluster random sampling), Sampel kelas diambil dari populasi sebanyak 2 kelas yaitu kelas $\mathrm{X}-10$ dengan menggunakan model inkuiri terbimbing dan kelas X-9 dengan menggunakan pembelajaran konvensional dengan jumlah siswa masing-masing 35 orang.

Hasil belajar siswa diperoleh dengan memberikan tes pada kedua kelas sebelum dan sesudah diberi perlakuan. Rancangan penelitian quasi eksperimen ini dengan desain two group pretest-posttest design. Rancangan penelitian ini ditunjukkan pada Tabel 2.

Tabel 2. Desain Penelitian (two group pretest-posttest design)

\begin{tabular}{llll}
\hline Sampel & Pretest & Perlakuan & Posttest \\
\hline Kelas & $\mathrm{T}_{1}$ & $\mathrm{X}_{1}$ & $\mathrm{~T}_{2}$ \\
Eksperimen & & & \\
\hline
\end{tabular}

\begin{tabular}{llll}
\hline Kelas & $\mathrm{T}_{1}$ & $\mathrm{X}_{2}$ & $\mathrm{~T}_{2}$
\end{tabular}

Kontrol

Keterangan :

$\mathrm{T}_{1} \quad=$ Pretest

$\mathrm{T}_{2} \quad=$ Posttestt

$\mathrm{X}_{1} \quad=$ Model Pembelajaran Inkuiri Terbimbing

$\mathrm{X}_{2} \quad=$ Pembelajaran Konvensional

Instrumen yang digunakan untuk mengumpulkan data hasil belajar siswa pada materi pokok Suhu dan kalor yang terdiri dari 8 soal dalam bentuk essay.

Uji hipotesis yang dikemukakan dilaksanakan dengan membandingkan rata-rata skor hasil belajar yang dicapai baik kelompok eksperimen maupun kelompok kontrol. Data yang diperoleh ditabulasikan kemudian dicari rataratanya. Sebelum dilakukan penganalisisan data, terlebih dahulu ditentukan skor masing-masing kelompok sampel lalu dilakukan pengolahan data dengan langkahlangkah sebagai berikut:

a) Menghitung nilai rata-rata dan simpangan baku

b) Uji Normalitas

c) Uji Homogenitas

Uji normalitas dan uji homogenitas dimaksudkan sebagai prasyarat melakukan uji hipotesis jika data terdistribusi noormal dan homogen.

d) Pengujian Hipotesis (Uji t)

Uji $t$ digunakan untuk mengetahui kesamaan kemampuan awal siswa pada kedua kelompok sampel dan untuk mengetahui pengaruh dari suatu perlakuan yaitu model pembelajaran inkuiri terbimbing terhadap hasil belajar siswa. 


\section{HASIL DAN PEMBAHASAN}

Hasil penelitian di SMA Negeri 15 Medan sebelum diberikan pembelajaran kepada kedua kelompok sampel diperoleh rata-rata pretest siswa kelas eksperimen 7,24 dan kelas kontrol 6,92. Hasil posttest setelah kedua kelas diberikan perlakuan dengan menggunakan model pembelajaran yang berbeda diperoleh bahwa rata-rata nilai hasil belajar siswa pada kelas eksperimen yang menggunakan model pembelajaran inkuiri terbimbing adalah 47,65 sedangkan pada kelas kontrol yang menggunakan pembelajaran konvensional diperoleh rata-rata nilai hasil belajar siswa adalah 41,95 .

Uji normalitas data pretes dan postes kelas eksperimen dan kelas kontrol menggunakan uji liliefors, setelah dilakukan pengujian maka data pretes dan postes kedua kelas terdistribusi normal. Uji homogenitas pretes dan postes kelas eksperimen dan kelas kontrol menggunakan uji kesamaan dua varians. Berdasarkan hasil pengujian ini data kedua kelompok sampel dinyatakan homogen sehingga layak dilakukan uji hipotesis dengan hasil uji hipotesis ditunjukkan pada Tabel 2.

Tabel 3. Ringkasan Perhitungan Uji Hipotesis Kemampuan Postes

\begin{tabular}{llcccc}
\hline $\mathbf{N}$ & Sampel & $\begin{array}{c}\text { Rata- } \\
\text { rata }\end{array}$ & $\mathbf{t}_{\text {hit }}$ & $\mathbf{t}_{\text {tabel }}$ & Kes \\
\cline { 1 - 3 } 1 & Eks & 47,56 & 2,37 & 1,67 & $\begin{array}{c}\text { Ha } \\
\text { diterima }\end{array}$ \\
\cline { 1 - 3 } 2 & Kon & 41,95 & & & \\
\hline
\end{tabular}

Observasi bertujuan untuk mengamati aktivitas siswa selama pembelajaran dengan model inkuiri terbimbing. Aktivitas siswa selama pembelajaran berlangsung mengalami kenaikan setiap pertemuannya, pada pertemuan I dengan rata-rata 62,38, pada pertemuan kedua dengan rata-rata 72,10 , dan pada pertemuan ke III dengan rata-rata 79,81. Hasil aktivitas digambarkan dalam diagram batang pada Gambar 1 .

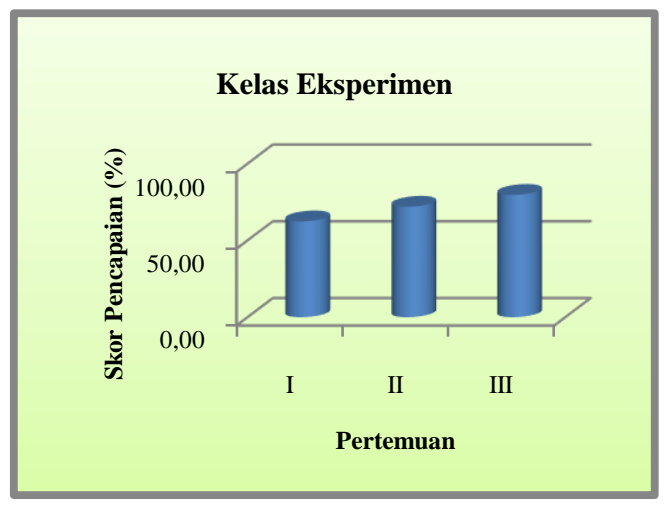

Gambar 1. Diagram Batang data aktivitas kelas eksperimen.

Aktivitas siswa mengalami peningkatan walaupun kemunculan setiap indikator tidak mencapai $100 \%$, namun peningkatan aktivitas siswa setiap pertemuan memperlihatkan antusias siswa yang semakin tinggi dalam kegiatan belajar mengajar berlangsung.

Berdasarkan hasil penelitian ini, terbukti bahwa model pembelajaran inkuiri terbimbing dapat meningkatakan hasil belajar dan aktivitas siswa.

Model pembelajan inkuiri terbimbing memiliki kelebihan yaitu, merupakan model pembelajaran (1) yang dapat membentuk self concep (konsep diri), sehingga terbuka terhadap pengalaman-pengalaman baru dan lebih kreatif, (2) tingkat pengharapan bertambah, yaitu ada kepercayaan diri serta ide tertentu 
bagaimana ia dapat menyelesaikan suatu tugas dengan caranya sendiri, (3) dapat mengembangkan bakat dan kecakapan individu, dan (4) dapat memberi waktu kepada pembelajar untuk mengasimilasi dan mengakomodasi informasi.

ini, $\begin{gathered}\text { Berdasarkan hasil penelitian } \\ \text { terbukti bahwa model }\end{gathered}$ pembelajaran inkuiri terbimbing dapat meningkatakan hasil belajar dan aktivitas siswa, hal ini juga sesuai dengan peneliti terdahulu yang dilakukan oleh Sulik (2014) yang mengatakan bahwa model inkuiri telah diususlkan sebagai salah satu penawar dan alternatif yang efektif untuk menggantikan pembelajaran tradisional. Model pembelajaran inkuiri juga dapat meningkatkan pengertian dan pemahaman siswa tidak hanya pada memanipulasi data tetapi juga mewakili observasi dan pengetahuan awal mereka.

Model pembelajaran inkuiri terbimbing juga memiliki kelemahan dan menjadi kendala selama proses pembelajaran berlangsung yaitu : (1) situasi yang kurang kondusif pada saat pembelajaran dimana pada fase pengumpulan data dan verifikasi ada sebagian siswa yang tidak membahas tentang materi yang sedang dipelajari justru membahas hal lain diluar materi, sehingga mengganggu suasana pembelajaran di kelas karna siswa lain tidak akan nyaman dalam belajar, selain itu kendala tersebut sangat berpengaruh pada tahap berikutnya karena pemahaman siswa pada tahap pengumpulan data dan verifikasi mempengaruhi efektifitas pembelajaran pada tahap eksperimen, (2) pada saat melakukan praktikum banyak siswa yang bertanya cara pertunjuk kerja selama praktikum, sementara petunjuk kerja tersebut sudah tertera didalam lembar kerja siswa (LKS), hal ini dikarenakan kurangnya minat siswa dalam membaca dan menemukan sendiri, sehingga membutuhkan waktu yang lebih lama untuk menjelaskan berulang-ulang petunjuk kerja dalam lembar kerja siswa (LKS) tersebut, dan (3) tidak terbiasanya siswa dituntut untuk berpikir tingkat tinggi menjadi kendala yang paling mendasar, sehingga saat diberikan model pembelajaran yang menuntut tingkat berpikir tinggi tidak semua siswa dapat mengikutinya.

\section{Kesimpulan}

Kesimpulan bahwa kemampuan hasil belajar dan aktivitas belajar menggunakan inkuiri terbimbing lebih baik bila dibanding dengan menggunakan metode konvensional. Penggunaan waktu dan pengelolaan kelas selama dalam pembelajaran harus diperhatikan dengan baik.

\section{Daftar Pustaka}

Arends, R. I., (2012), Learning To Teach $9^{\text {th }}$ Edition, McGrawHill Companies, INC

Husein, A., Azeem, M., and Shakoor, Azra., 2011, Physics Teaching Methods: Scientific Inquiry Vs Tradtional Lecture, International Journal of Humanities and Social Science, Vol. 1. No. 19, Hal 269-276.

Kunandar, (2007), Guru Profesional, Rajawali Pers, Jakarta 
Njoroge, G., N., Changeiywo, J., M., and Ndirangu, M., 2014, Effect of Inquiry-Based Teaching Approach on Secondary School Students' Achievment and Motivation in Physics In Nyeri County, Kenya, Full Length Research Paper, Vol. 2. No. 1. Hal 1-16

Ngozi, L., N., and Vivian, V., O., 2013, Effect of Guided Inquiry with Analogy Instructional Strategy on Students Acquisition of Sciece Process Skills, Journal of Education and Practice, Vol.4. No. 27, Hal 35-40

Rachman, N., Sudarti, dan Supriadi, B., 2012, Penerapan Model Inkuiri Terbimbing (Guided Inquiry Approach) pada Pembelajaran Fisika Kelas VIII-8 SMP Negeri 3 Rogojampi Tahun Ajaran 2012/2013, Jurnal Pembelajaran Fisika, Hal.300308

Sanjaya, W., (2011). Strategi Pembelajaran Berorientasi Standard Proses Pendidikan. Jakarta:Kencana Prenada Media

Seraphin, K.D., Philippoff, J., Pariski, A., Degnan, K., and Warren, D.P., (2012), Teaching Energy Science as Inquiry: Reflections on Profsional Development as a Tool to Build Inqury Skills for Middle and High Schol Teachers, Journal of Science Technology, 22:235-251.
Sudjana., (2005). Metode Statistika, Bandung: Penerbit Tarsito.

Sulik, E., 2014, Using Cognitive Science To Inform InquiryBased Approaches To High School Science, MATL Capstone Research Project Literature Review

Trianto., (2011). Mendesain Model Pembelajaran Inovatif dan Progresif. Jakarta: Kencana Prenada Media Group.

Vlassi, M., and Karaliota, A., 2012, The Comparison Between Guided Inquiry and Traditional Teaching Method. A Case Study for The Teaching of The Structure of Matter to 8th Grade Greek Students, Procedia-Social and behavioral Sciences 93. Hal 494-497.

Wang, H., and Pose, L., 2011, An Inquiry-Based Linear Algebra Class, Online Submission, USChina Education Review, $B$ Vol 4, Hal. 489-494. 